\title{
Acid is Key to the Radical-Trapping Antioxidant Activity of Nitroxides
}

\author{
Supporting Information \\ Evan A. Haidasz, ${ }^{\star}$ Derek Meng, ${ }^{\ddagger}$ Riccardo Amorati, ${ }^{\circledR}$ Andrea Baschieri, ${ }^{\circledR}$ Keith U. Ingold, ${ }^{\S}$ \\ Luca Valgimigli ${ }^{\mathbb{T} * *}$ and Derek A. Pratt ${ }^{\ddagger * *}$ \\ $\ddagger$ Department of Chemistry, University of Ottawa, Ottawa, Ontario K1N 6N5, Canada, \\ qDepartment of Chemistry “G. Ciamician”, University of Bologna, Bologna, I-40126, Italy, and \\ $\S N a t i o n a l$ Research Council of Canada, Ottawa, Ontario K1A 0R6, Canada. \\ dpratt@uottawa.ca,luca.valgimigli@unibo.it
}

Table of Contents

Synthetic Procedures $\quad$ S2

Model Reaction Data $\quad$ S4

$\mathrm{TEMPO}^{+} \mathrm{BF}_{4}^{-}$Reactions Monitored by UV-Vis Spectroscopy $\quad$ S6

Inhibited Autoxidations $\quad$ S8

EPR Experiments $\quad$ S13

High Temperature Autoxidation Data $\quad$ S16

CBS-QB3 Computational Results and Structures $\quad$ S18

$\begin{array}{ll}\text { References } & \text { S22 }\end{array}$ 


\section{Synthetic Procedures}

Azocumene. Azocumene was synthesized via the procedure reported by Ikeda, ${ }^{1}$ and as had been previously synthesized by our lab. ${ }^{2}$
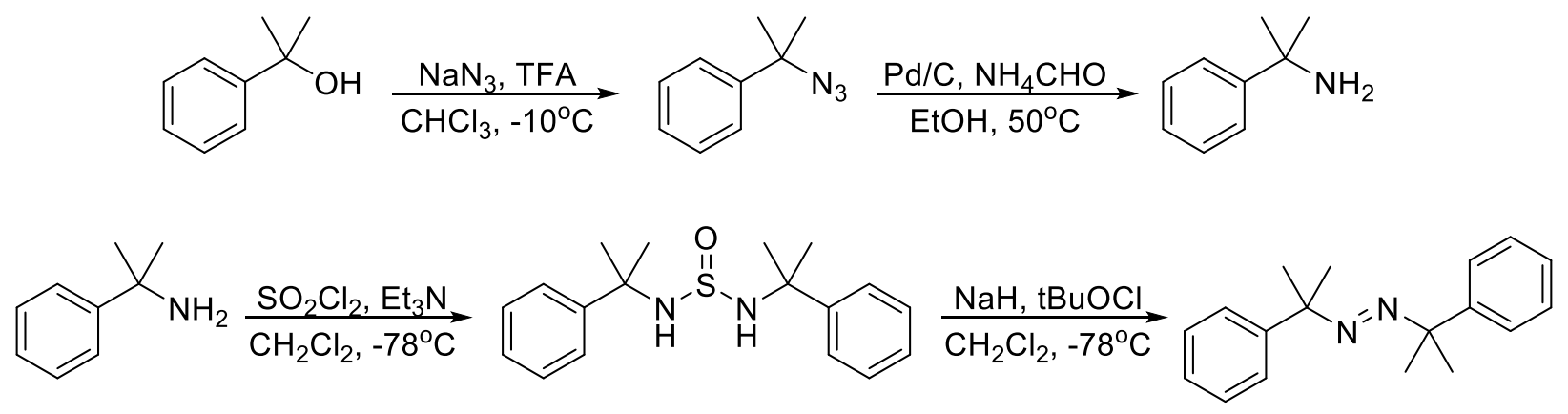

To a solution of cumyl alcohol $(10 \mathrm{mmol})$ and sodium azide $(22 \mathrm{mmol})$ in $10 \mathrm{~mL} \mathrm{CHCl}_{3}$ cooled to $-10{ }^{\circ} \mathrm{C}$ was added TFA (55 mmol) dropwise as a solution in $10 \mathrm{~mL} \mathrm{CHCl}_{3}$. The solution was stirred overnight and upon reaction completion (by TLC) was quenched with water. Following extraction with $\mathrm{CH}_{2} \mathrm{Cl}_{2}$, the organics were washed with brine, dried over $\mathrm{MgSO}_{4}$, and concentrated. The crude cumylazide was then dissolved in $50 \mathrm{~mL}$ EtOH and ammonium formate $(50 \mathrm{mmol})$ and $10 \% \mathrm{Pd} / \mathrm{C}(100 \mathrm{mg})$ were added. The reaction was stirred at $50{ }^{\circ} \mathrm{C}$ overnight. Upon completion, the solution was diluted with ether and filtered through a pad of silica to afford cumylamine as a pale yellow oil. Yield: $72 \%$. Spectral data were consistent with those in the literature. ${ }^{1}$

To a solution of cumylamine $(10 \mathrm{mmol})$ and dry $\mathrm{Et}_{3} \mathrm{~N}(11 \mathrm{mmol})$ in dry $\mathrm{CH}_{2} \mathrm{Cl}_{2}(10 \mathrm{~mL})$ cooled to $-78^{\circ} \mathrm{C}$ was added sulfuryl chloride $(5.1 \mathrm{mmol})$ dropwise. The reaction was maintained at $-78{ }^{\circ} \mathrm{C}$ until completion, as determined by TLC. The reaction was quenched by addition of water, extracted with $\mathrm{CH}_{2} \mathrm{Cl}_{2}$ and the organics were washed with brine, dried over $\mathrm{MgSO} 4$, and concentrated. Recrystallization from EtOH afforded white needles. Yield: $71 \%$. Spectral data were consistent with those in the literature. ${ }^{1}$

To a suspension of $\mathrm{NaH}(2.1 \mathrm{mmol})$ in dry THF cooled to $0{ }^{\circ} \mathrm{C}$ was added N,N-bis(1-methyl-1phenethyl)-sulfamide (3, $1.0 \mathrm{mmol})$ as a solution in THF dropwise. After 2 hours, the solution was cooled to $-78{ }^{\circ} \mathrm{C}$ and tert-butylhypochlorite $(1.1 \mathrm{mmol})$ was added dropwise. The solution was allowed to warm to room temperature and then quenched with water and extracted with $\mathrm{Et}_{2} \mathrm{O}$. Organics were washed with brine, dried over $\mathrm{MgSO}_{4}$, and concentrated. Purification by column chromatography (Pet Ether/Et ${ }_{2} \mathrm{O}$ ) afforded azocumene which was then further purified by recrystallization from Hexanes $/ \mathrm{CH}_{2} \mathrm{Cl}_{2}$ at $-20{ }^{\circ} \mathrm{C}$. Yield $11 \%$. Spectral data were consistent with those in the literature. ${ }^{1}$

Azobis(1-phenylethane). The title compounds was synthesized by a modified version of a literature procedure. ${ }^{14,15}$ Briefly, acetophenone $(12 \mathrm{~mL}, 100 \mathrm{mmol})$ and hydrazine hydrate $(2.5 \mathrm{~mL}, 50 \mathrm{mmol})$ were dissolved in $50 \mathrm{~mL}$ of EtOH, $p$-toluenesulfonic acid $(190 \mathrm{mg}, 1.0 \mathrm{mmol})$ was added and the mixture was refluxed for 3 hours. Upon cooling to room temperature, a light yellow precipitate had formed. The precipitate was filtered and dried under vacuum, giving $10.2 \mathrm{~g}$ of pure acetophenone azine. Yield $86 \%$. 
Acetophenone azine $(7.0 \mathrm{~g}, 4.2 \mathrm{mmol}), \mathrm{Pd} / \mathrm{C}(350 \mathrm{mg})$ and $\mathrm{EtOH}(45 \mathrm{~mL})$ were combined in a high pressure hydrogenation apparatus, which was then purged with nitrogen, and pressurized to $1500 \mathrm{psi}$ with hydrogen. The reaction was stirred and heated to $50^{\circ} \mathrm{C}$ for 2 hours, filtered through Celite and concentrated to give $6.2 \mathrm{~g}$ of crude bis(1-phenethyl)hydrazine. Yield $89 \%$.

The crude bis(1-phenethyl)hydrazine $(6.2 \mathrm{~g}, 26 \mathrm{mmol})$ was dissolved in $n$-heptane $(100 \mathrm{~mL})$ and oxygen gas was bubbled through the solution until the reaction was complete by TLC. The solvent was removed (not heating past $30^{\circ} \mathrm{C}$ ) and the crude product was purified by column chromatography (eluting with 5\% EtOAc/Hexanes) and then recrystallized from $\mathrm{MeOH}$ to give $3.0 \mathrm{~g}$ of azobis(1-phenylethane). Yield 48\%. Spectral data were consistent with those in the literature. ${ }^{15}$

$\boldsymbol{T E M P O}^{+} \boldsymbol{B F}_{4}^{-}$. $\mathrm{TEMPO}^{+} \mathrm{BF}_{4}^{-}$was synthesized through the procedure of Holan and $\mathrm{Jahn}^{3}$ Isoamyl nitrite $(1.0 \mathrm{mmol})$ was added slowly to a solution of $\mathrm{BF}_{3}-\mathrm{OEt}_{2}(1.3 \mathrm{mmol})$ in dry $\mathrm{Et}_{2} \mathrm{O}(4.5 \mathrm{~mL})$ under argon. The solution was stirred 5 minutes before a solution of TEMPO $(156 \mathrm{mg})$ in $0.5 \mathrm{~mL} \mathrm{Et}_{2} \mathrm{O}$ was added dropwise over 20 minutes. The solution was stirred an additional 10 minutes. The precipitate was filtered, washed thoroughly with $\mathrm{Et}_{2} \mathrm{O}$, and dried under vacuum. Yield $42 \%$.

\section{4,4'-[(1,10-dioxo-1,10-decanediyl)bis(oxy)]bis[2,2,6,6-tetramethyl-1-oxo-piperidinium]}

tetrafluoroborate. The oxidation of nitroxide 2 to its corresponding oxoammonium salt was accomplished by an identical procedure to that shown above for the preparation of $\mathrm{TEMPO}^{+} \mathrm{BF}_{4}^{-}$. The yellow oily solid thus obtained was rinsed thoroughly with diethyl ether, and solidified completely under vacuum overnight. It was stored under vacuum until immediately before use. Spectral data are consistent with reported data for the nitrate salt. ${ }^{12}$ FT-IR (ATR): 2931, 1463, 1387, 1235, 1167, 1060 (oxoammonium salt); 1729 (ester), 984 (nitroxide).

Cumyl-TEMPO. Azocumene $(1.5 \mathrm{mmol})$ and TEMPO $(3.0 \mathrm{mmol})$ were dissolved in thoroughly degassed $\mathrm{MeCN}(15 \mathrm{~mL})$. The solution was stirred at $50^{\circ} \mathrm{C}$, under argon, for $24 \mathrm{~h}$. The solvent was removed under vacuum, and the residue purified by column chromatography with $\mathrm{Et}_{2} \mathrm{O} /$ hexanes to yield a white solid. Yield: $69 \%$. Spectral data are consistent with those in the literature. ${ }^{4}$

1-Phenethyl-TEMPO. The compound was synthesized through the literature procedure. Spectral data are consistent with those in the literature. ${ }^{13}$ 


\section{Model Reaction Data}

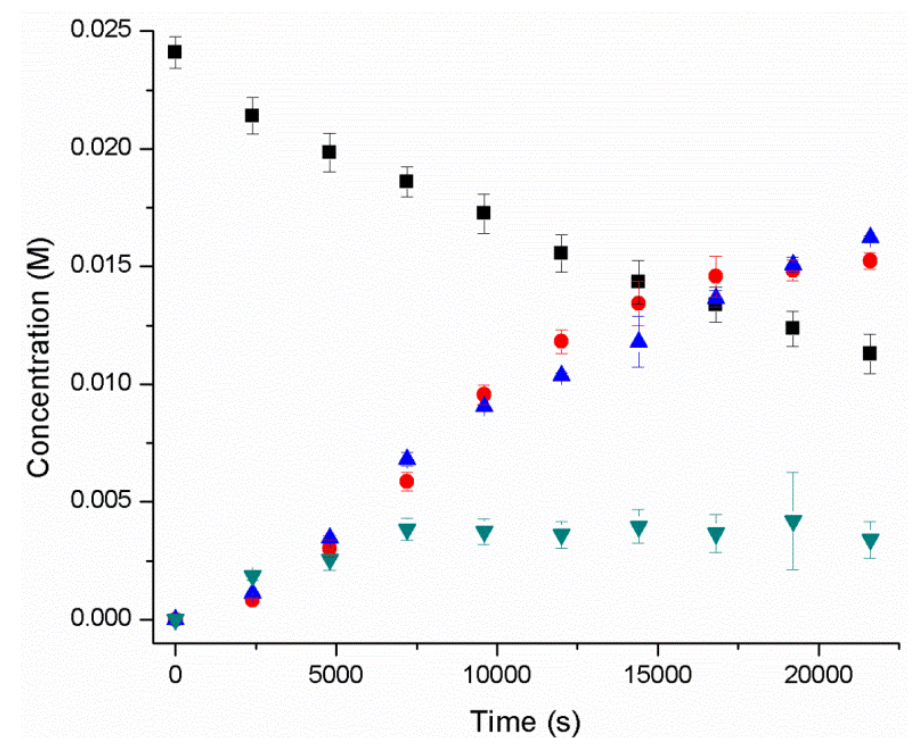

Figure S1. Decomposition of azocumene ( $\square$ ) and formation of the TEMPO-cumyl adduct in the reaction of azocumene $(25 \mathrm{mM})$ and $\mathrm{TEMPO}^{+} \mathrm{BF}_{4}^{-}(25 \mathrm{mM})$ in the presence of $\mathrm{Me}_{4} \mathrm{~N}^{+} \mathrm{AcO}^{-}(25 \mathrm{mM})$ in acetonitrile at $50^{\circ} \mathrm{C}$ under argon with no additive (•), $25 \mathrm{mM} \mathrm{AcOH}(\boldsymbol{\Delta})$ or $25 \mathrm{mM}$ TFA ( $\left.\boldsymbol{\nabla}\right)$. Concentrations were determined by HPLC as described in the Experimental Section.

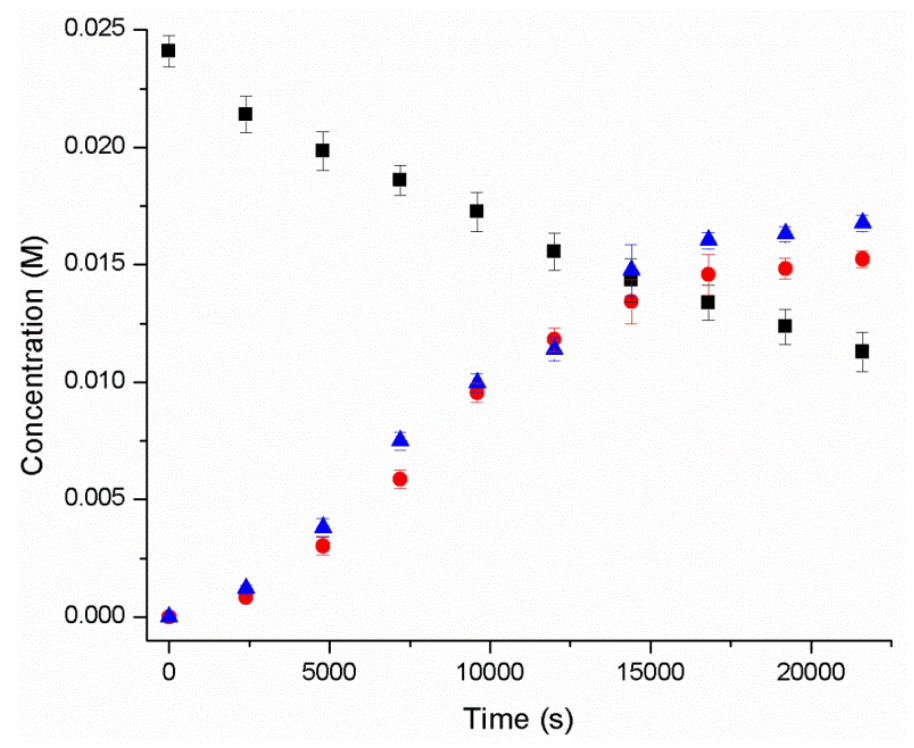

Figure S2. Decomposition of azocumene ( $\square$ ) and formation of the TEMPO-cumyl adduct in the reaction of azocumene $(25 \mathrm{mM})$ and $\mathrm{TEMPO}^{+} \mathrm{BF}_{4}^{-}(25 \mathrm{mM})$ in the presence of $\mathrm{Me}_{4} \mathrm{~N}^{+} \mathrm{AcO}^{-}(25 \mathrm{mM})$ at $50^{\circ} \mathrm{C}$ under argon in acetonitrile $(\bullet)$ or chlorobenzene $(\boldsymbol{\Delta})$.Concentrations were determined by HPLC as described in the Experimental Section. 


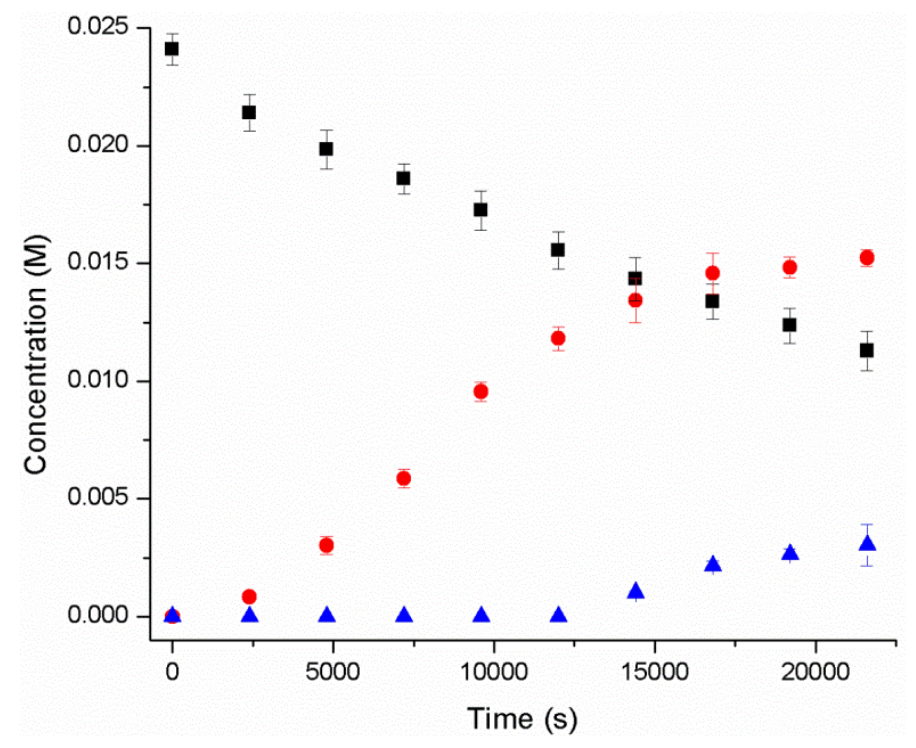

Figure S3. Decomposition of azocumene ( $\square$ ) and formation of the TEMPO-cumyl adduct in the reaction of azocumene $(25 \mathrm{mM})$ and $\mathrm{TEMPO}^{+} \mathrm{BF}_{4}^{-}(25 \mathrm{mM})$ at $50^{\circ} \mathrm{C}$ under argon in acetonitrile in the presence (•) or absence $(\boldsymbol{\Delta})$ of $25 \mathrm{mM} \mathrm{Me}_{4} \mathrm{~N}^{+} \mathrm{AcO}^{-}$. Concentrations were determined by HPLC as described in the Experimental Section.

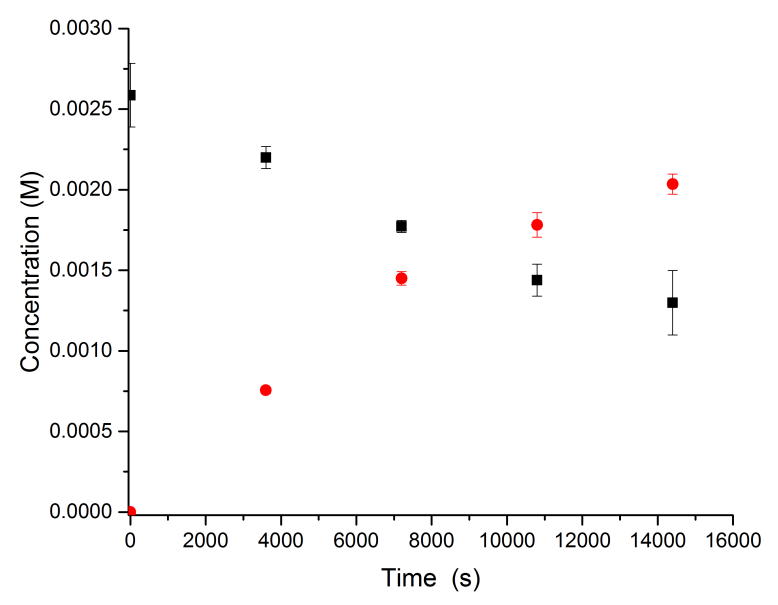

Figure S4. Decomposition of azobis(1-phenylethane) (ם) and formation of the TEMPO-phenethyl adduct $(\bullet)$ in the reaction of azobis(1-phenylethane) $(25 \mathrm{mM})$ and $\mathrm{TEMPO}^{+} \mathrm{BF}_{4}^{-}(25 \mathrm{mM})$ at $100^{\circ} \mathrm{C}$ under nitrogen in chlorobenzene in the presence of $25 \mathrm{mM} \mathrm{Me}_{4} \mathrm{~N}^{+} \mathrm{AcO}^{-}$. Concentrations were determined by HPLC as described in the Experimental Section. 
TEMPO $^{+} \mathrm{BF}_{4}^{-}{ }^{-}$Reactions Monitored by UV-Vis Spectroscopy
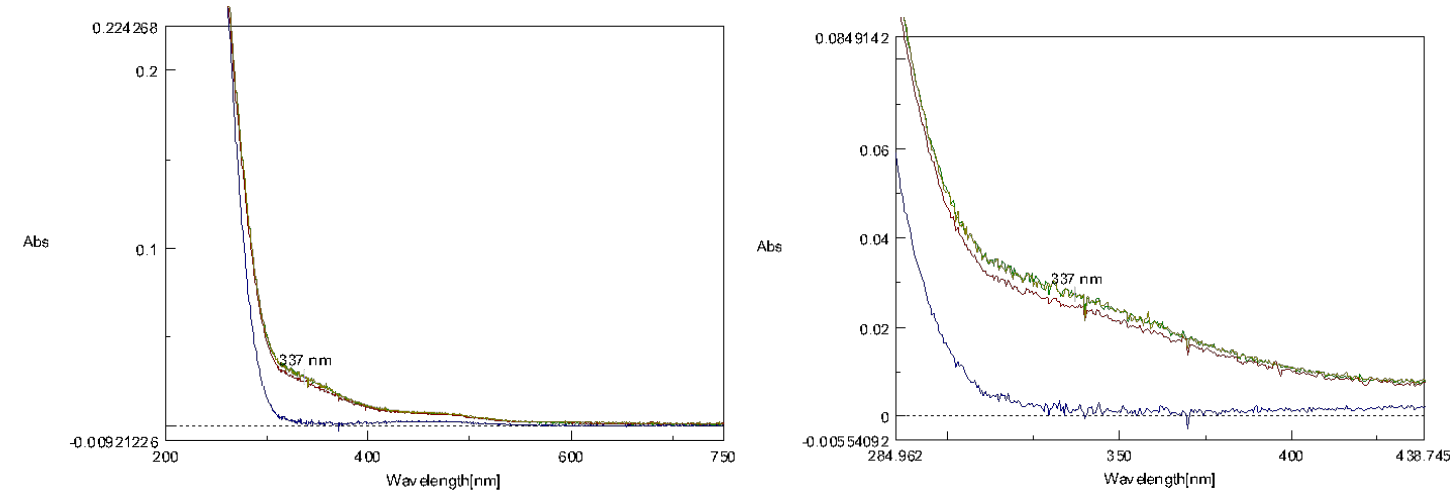

Figure S5. UV-Vis spectra in acetonitrile at $20^{\circ} \mathrm{C}$ of the mixture of $\mathrm{TEMPO}^{+} \mathrm{BF}_{4}^{-}(0.2 \mathrm{mM})$ and tert-butyl hydroperoxide (3.3 mM) immediately after mixing (green) and after 137 minutes (red). The blue line shows the spectra of a reference solution of TEMPO $(0.2 \mathrm{mM})$ in acetonitrile.

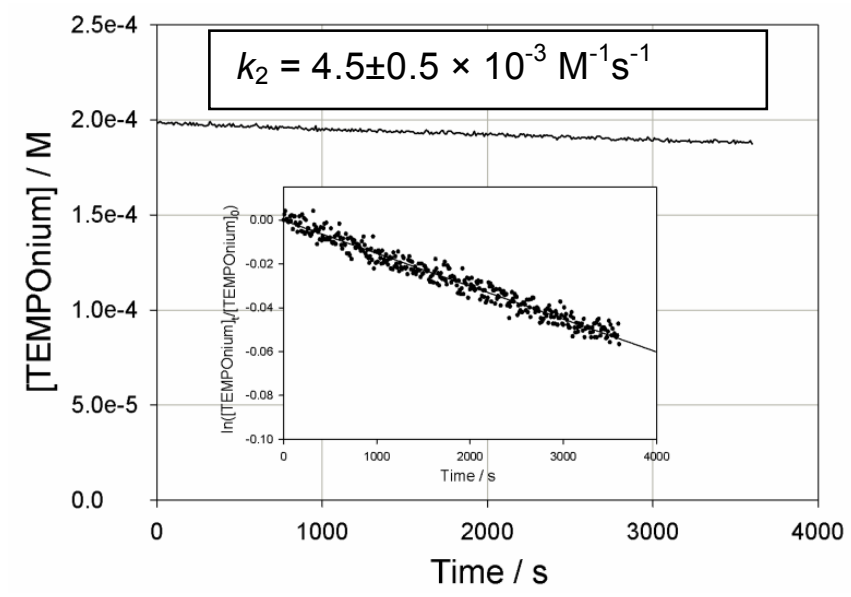

Figure S6. Reaction of TEMPO ${ }^{+} \mathrm{BF}_{4}^{-}(0.2 \mathrm{mM})$ with tert-butyl hydroperoxide $(3.3 \mathrm{mM})$ in acetonitrile at $20^{\circ} \mathrm{C}$ monitored at $337 \mathrm{~nm}$. The first-order signal decay is shown in the insert. 

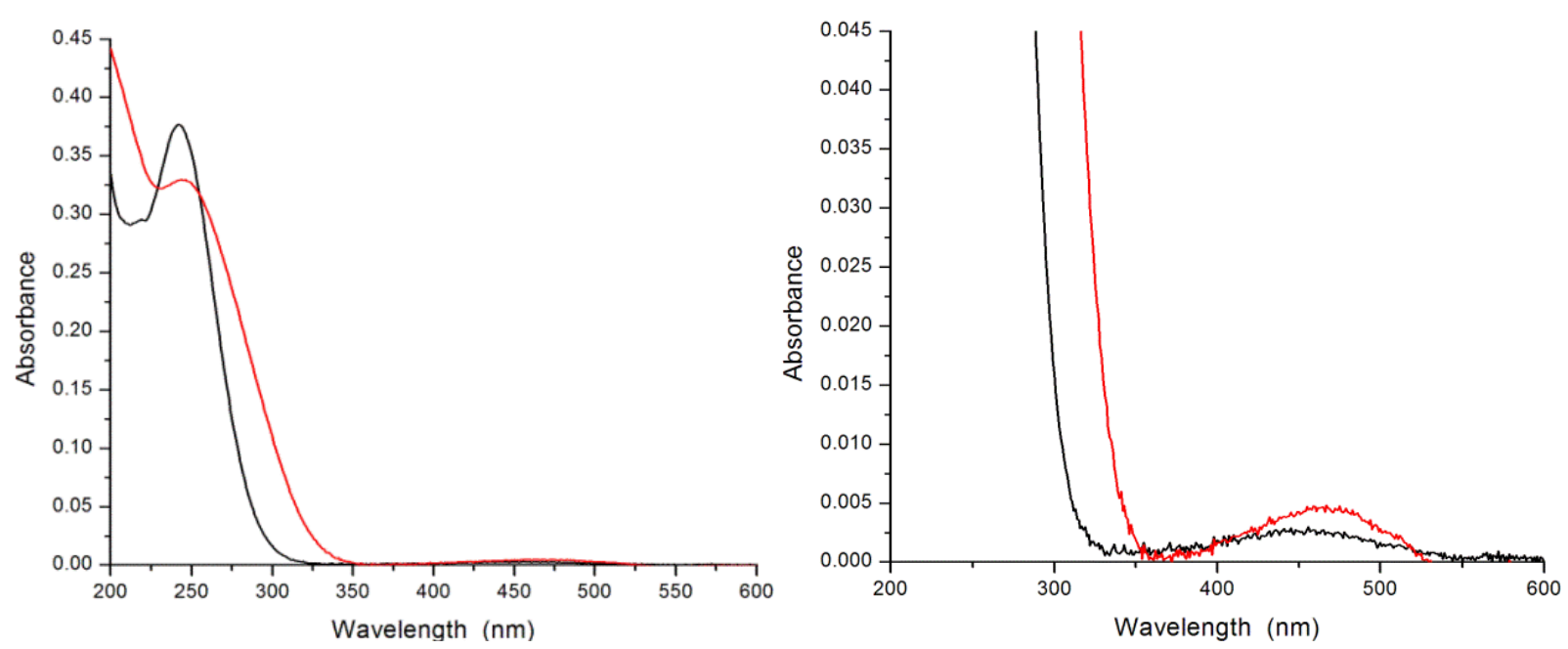

Figure S7. UV-Vis spectra of $0.4 \mathrm{mM}$ TEMPO (black) and $\mathrm{TEMPO}^{+} \mathrm{BF}_{4}^{-}$(red) in acetonitrile at $50^{\circ} \mathrm{C}$.

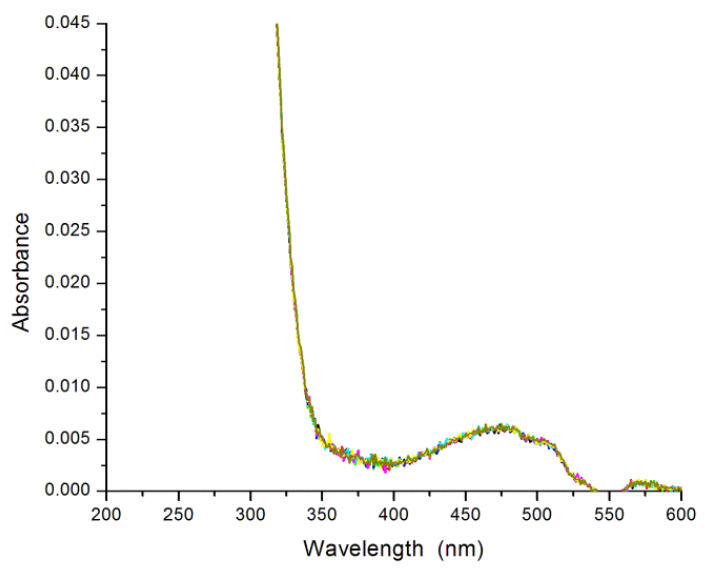

Figure S8. Incubation of TEMPO ${ }^{+} \mathrm{BF}_{4}^{-}(0.4 \mathrm{mM})$ in $1 \% \mathrm{H}_{2} \mathrm{O} / \mathrm{MeCN}$ with TFA $(10 \mathrm{mM})$ for 200 minutes (green through pink, indistinguishable). 

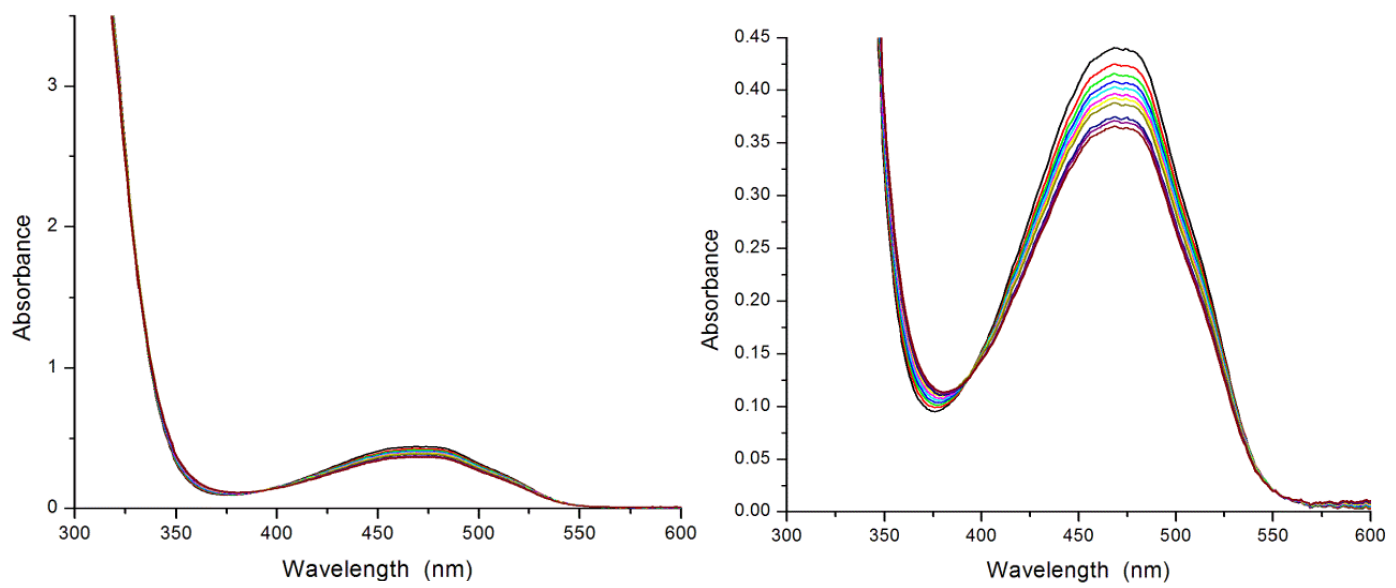

Figure S9. UV-Vis spectra of the decomposition of TEMPO ${ }^{+} \mathrm{BF}_{4}^{-}(20 \mathrm{mM})$ in $1 \% \mathrm{H}_{2} \mathrm{O} / \mathrm{MeCN}$ containing $0.1 \mathrm{M} \mathrm{TFA}$, at $70^{\circ} \mathrm{C}$. Spectra were taken every 4 minutes over the course of 40 minutes and yielded a decomposition rate of $R=1.3 \times 10^{-6} \mathrm{Ms}^{-1}$.

\section{Inhibited Autoxidations}

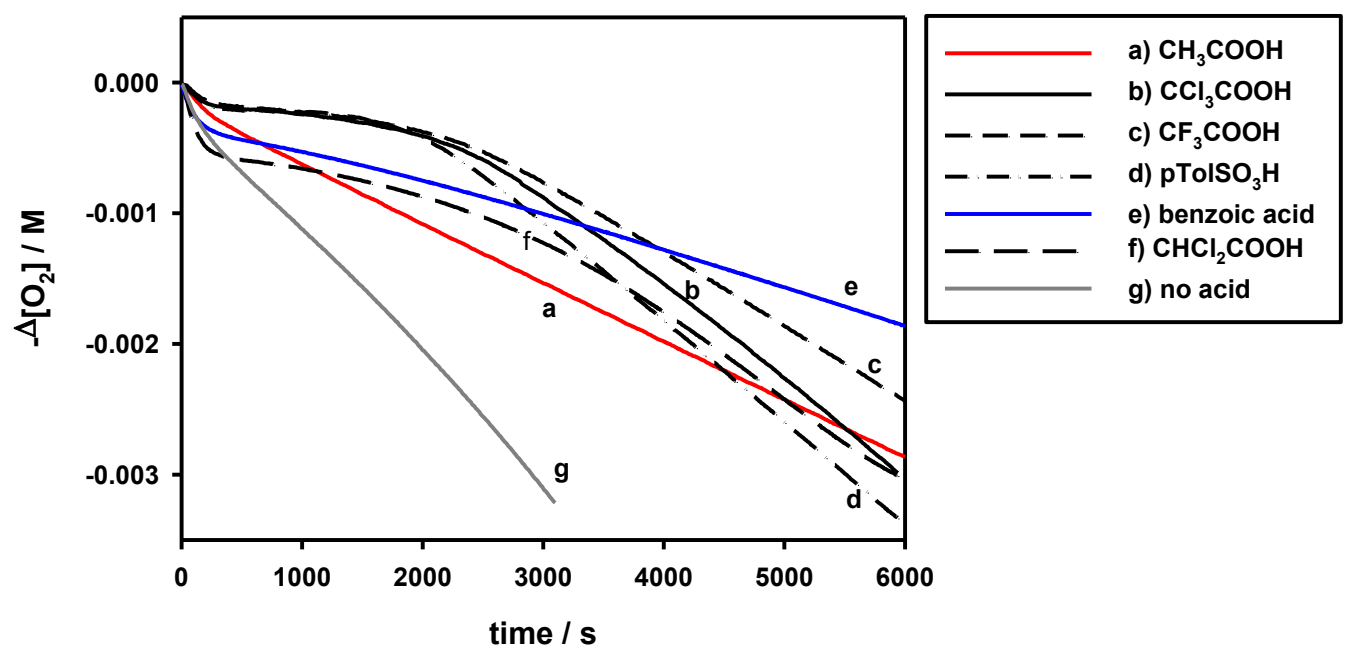

Figure S10. Oxygen consumption plots measured during the autoxidation of styrene $(4.3 \mathrm{M})$ in $\mathrm{MeCN}$ $\left(+1 \% \mathrm{H}_{2} \mathrm{O}\right)$ initiated by AIBN $(0.05 \mathrm{M})$ at $30{ }^{\circ} \mathrm{C}$ in the presence of TEMPO $(13 \mu \mathrm{M})$ and $4.3 \mathrm{mM}$ of various acids. 


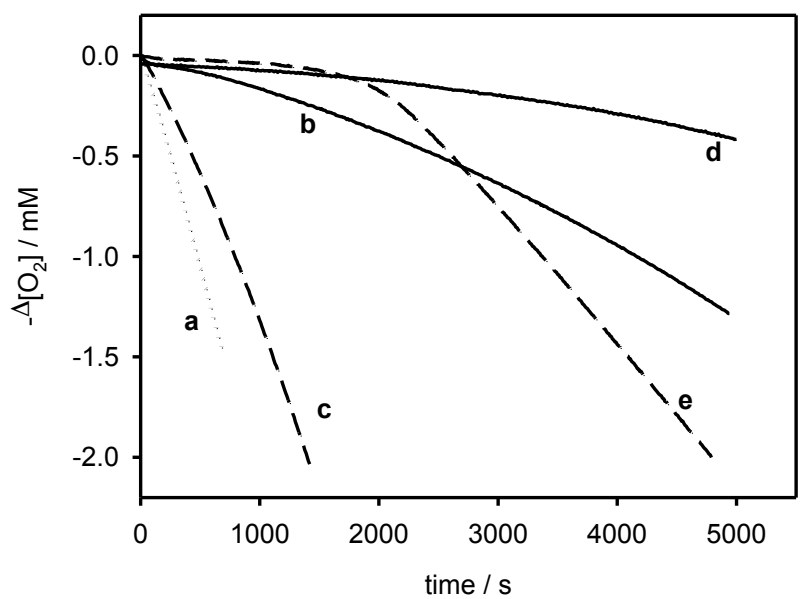

Figure S11. Inhibited autoxidation of styrene $(4.3 \mathrm{M})$ initiated by $\mathrm{AIBN}(0.05 \mathrm{M})$ in $\mathrm{MeCN}$ with $1 \% \mathrm{H}_{2} \mathrm{O}$ in (a) the absence of inhibitors, and in the presence of $13 \mu \mathrm{M}$ of either TEMPO ${ }^{+} \mathrm{BF}_{4}^{-}$(b and c) or TEMPO ( $\mathrm{d}$ and e) with added acetic acid (43 mM, solid lines) or trifluoroacetic acid ( $32 \mathrm{mM}$, dashed lines).
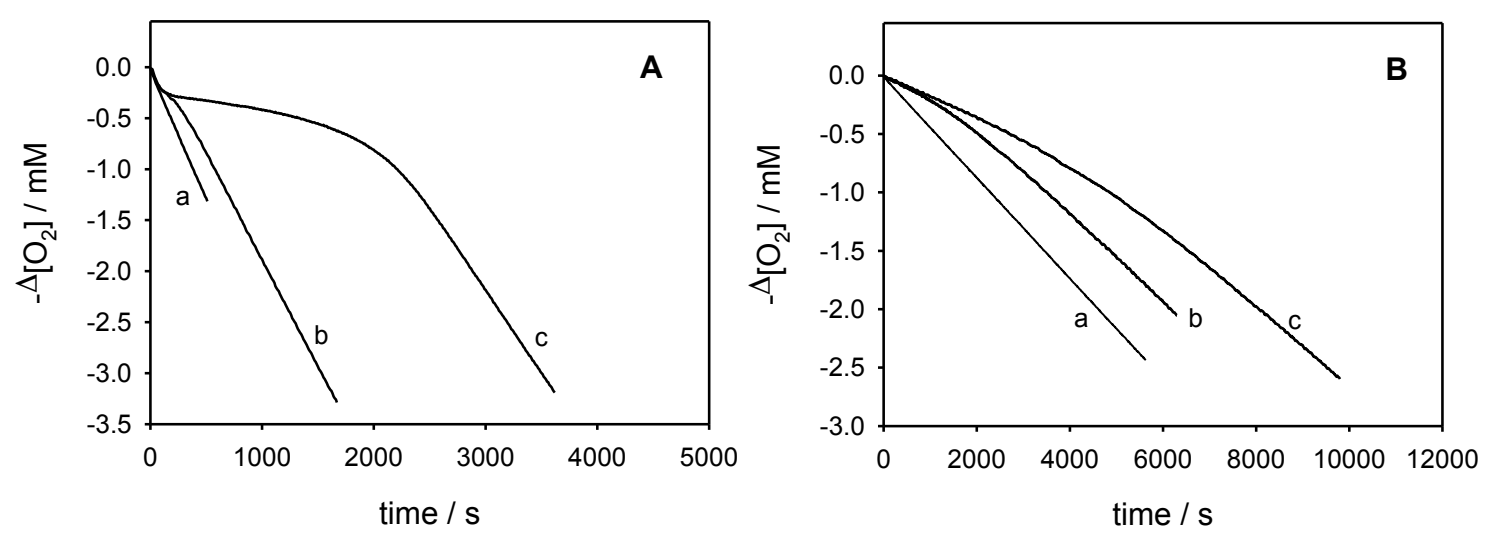

Figure S12. Oxygen consumption observed during the autoxidation of styrene (panel A) or of cumene (panel B) initiated by $\mathrm{AIBN}(0.05 \mathrm{M})$ at $30^{\circ} \mathrm{C}$ using in chlorobenzene. a) without inhibitors; b) $\mathrm{TEMPO}^{+} \mathrm{BF}_{4}^{-}(13 \mu \mathrm{M})$ and $\mathrm{AcOH}(44 \mathrm{mM})$; c) TEMPO $(13 \mu \mathrm{M})$ and $\mathrm{AcOH}(44 \mathrm{mM})$. 
The $\mathrm{O}_{2}$ consumption plots were analyzed on the basis of the mechanism reactions 1-8 by using Gepasi software $^{5}$ (see Figure S13).

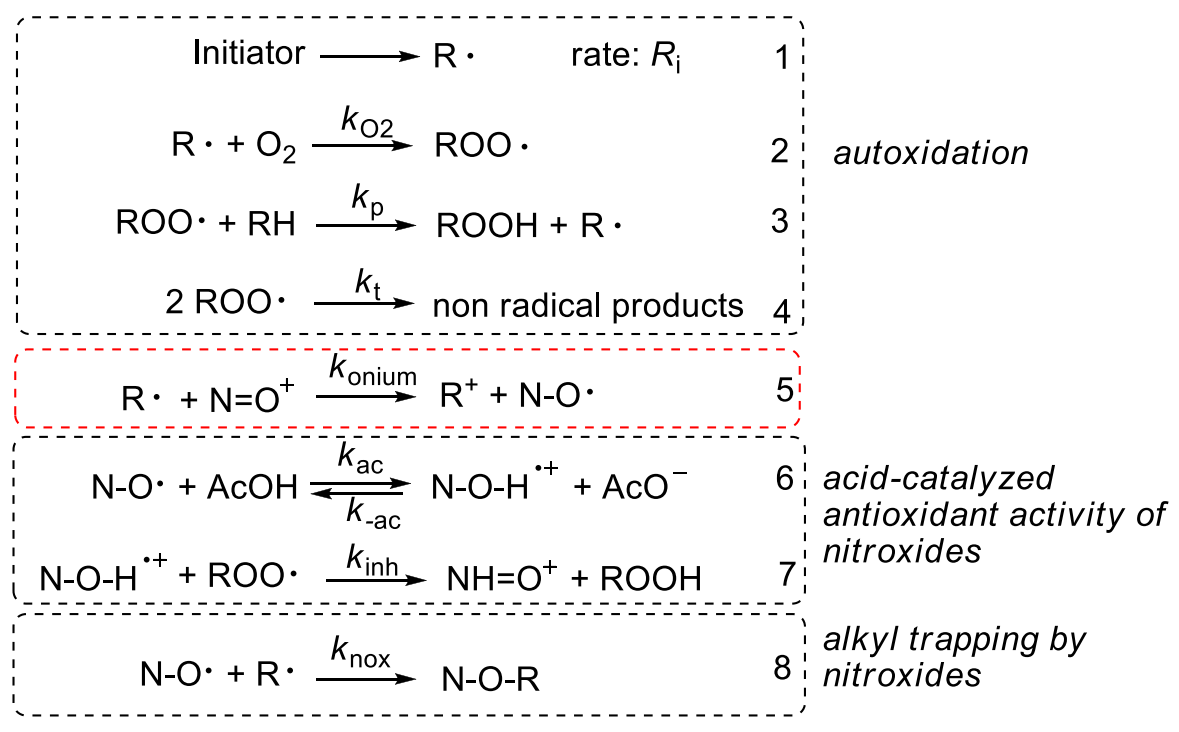

This procedure afforded the value of $k_{\text {onio }}$ (reaction 5) and the equilibrium constant $k_{\text {ac }} / k_{\text {ac }}$ (reaction 6).

The rate constants for reactions 3 and 4 were from the literature $\left(k_{\mathrm{p}}=41 \mathrm{M}^{-1} \mathrm{~s}^{-1}, 2 \mathrm{k}_{\mathrm{t}}=4.2 \times 10^{7} \mathrm{M}^{-1} \mathrm{~s}^{-1}\right)^{6}$, while the rate of initiation $\mathrm{R}_{\mathrm{i}}$ was experimentally determined as $6.1 \times 10^{-9} \mathrm{Ms}^{-1}$ by using PMC as reference antioxidant. The reaction of styryl radicals with $\mathrm{O}_{2}$ in $\mathrm{MeCN}$ was set equal to that of benzyl radicals with $\mathrm{O}_{2}\left(3.42 \times 10^{9} \mathrm{M}^{-1} \mathrm{~s}^{-1}\right)^{7}$, the backward reaction 6 was fixed at the diffusion controlled limit $\left(k_{\text {-ac }}=5 \times 10^{9} \mathrm{M}^{-}\right.$ $\left.{ }^{1} \mathrm{~s}^{-1}\right)^{8}$, while reaction 8 was fixed to $4.9 \times 10^{8} \mathrm{M}^{-1} \mathrm{~s}^{-1}$, as reported for benzyl radicals and TEMPO ${ }^{9}$. The reaction between protonated nitroxide and peroxyl radicals $k_{\text {inh }}$ (reaction 7) was set equal to $2 \times 10^{8} \mathrm{M}^{-1} \mathrm{~s}^{-1}$ on the basis of our previous results (the highest measured rate constant was $1.8 \times 10^{8} \mathrm{M}^{-1} \mathrm{~s}^{-1}$ with $10 \mathrm{mM}$ TSA). ${ }^{10}$ The concentration of oxygen was calculated from the known solubility at $30{ }^{\circ} \mathrm{C}$ as $\left[\mathrm{O}_{2}\right]=1.8$ $\mathrm{mM}$.

The results of the fittings of the autoxidations of styrene inhibited by TEMPO and TEMPOonium in the presence of different concentrations of acetic acid afforded $k_{\text {onium }}=(2.4 \pm 0.4) \times 10^{10} \mathrm{M}^{-1} \mathrm{~s}^{1}$ and $k_{\text {ac }} / k_{\text {-ac }}=$ $(1.3 \pm 0.6) \times 10^{-6}$. The rate constants $k_{\text {onium }}$ are similar to those reported for the reaction of $\mathrm{Ar}_{2} \mathrm{CH}^{+}$and bromide in $\mathrm{MeCN}\left(2 \times 10^{10} \mathrm{M}^{-1} \mathrm{~s}^{-1}\right){ }^{11}$ 


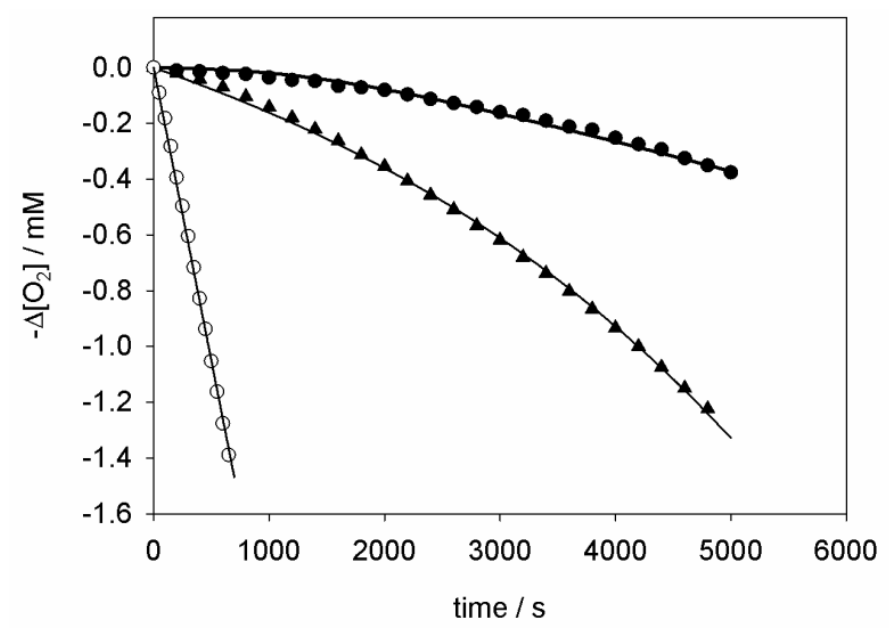

Figure S13. Inhibited autoxidation of styrene $(4.3 \mathrm{M})$ initiated by AIBN $(0.05 \mathrm{M})$ in MeCN with $1 \%$ of water and acetic acid $(0.043 \mathrm{M})$, in the absence of inhibitors $(\circ)$ or in the presence of TEMPO $(13 \mu \mathrm{M}, \bullet)$ or $\mathrm{TEMPO}^{+}(13 \mu \mathrm{M}, \boldsymbol{\Delta})$. Lines represent the results from numerical fittings, see text. 


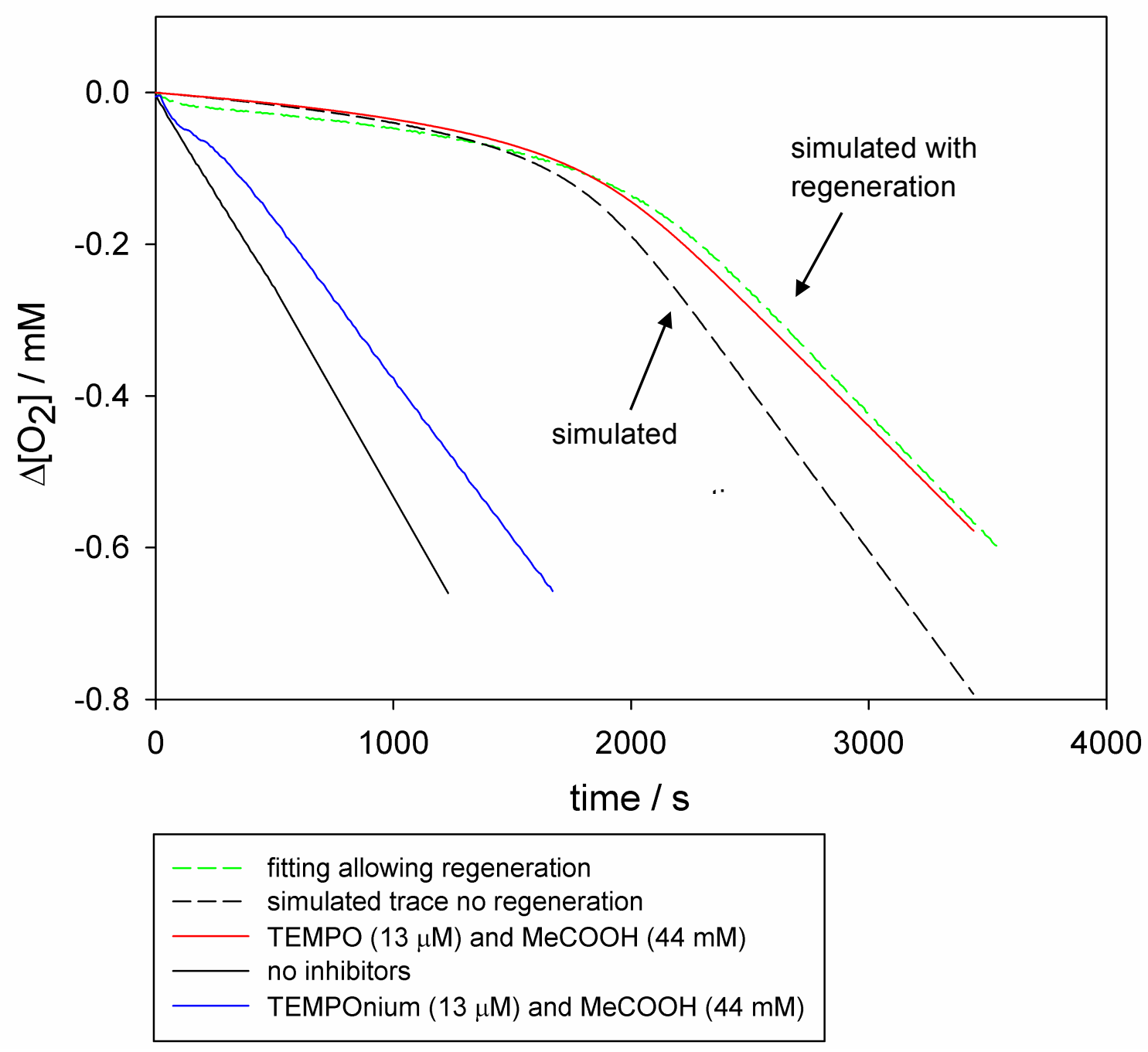

Figure S14. Oxygen uptake plots recorded during the autoxidation of styrene $(50 \% \mathrm{v} / \mathrm{v})$ in chlorobenzene, initiated by AIBN $0.05 \mathrm{M}$ at $303 \mathrm{~K}$, in the absence of inhibitors or in the presence of 13 $\mu \mathrm{M}$ TEMPO $+44 \mathrm{mM}$ acetic acid or $13 \mu \mathrm{M} \mathrm{TEMPO}^{+} \mathrm{BF}_{4}^{-}+44 \mathrm{mM}$ acetic acid as indicated in the legend. Simulated traces impose no regeneration of TEMPO from $\mathrm{TEMPO}^{+}$(black) or allow for regeneration (green). Best fittings afforded $k_{\text {reg }}\left(=k_{\text {onium }}\right)=1-2 \times 10^{9} \mathrm{M}^{-1} \mathrm{~s}^{-1}$. 


\section{EPR Experiments}

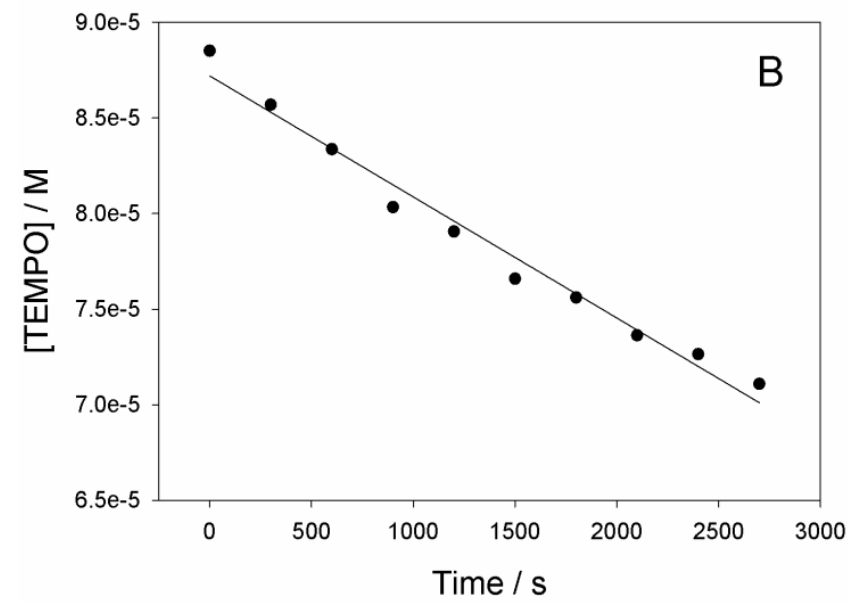

Figure S15. TEMPO concentration determined by EPR during the autoxidation (at $303 \mathrm{~K}$ initiated by AIBN $0.05 \mathrm{M})$ of $40 \%(\mathrm{v} / \mathrm{v})$ cumene in acetonitrile in the presence of $\mathrm{TEMPO}^{+} \mathrm{BF}_{4}^{-}(0.66 \mathrm{mM})$ upon addition of $26 \mathrm{mM}$ trifluoroacetic acid after $\sim 0.1 \mathrm{mM}$ TEMPO had already been formed.
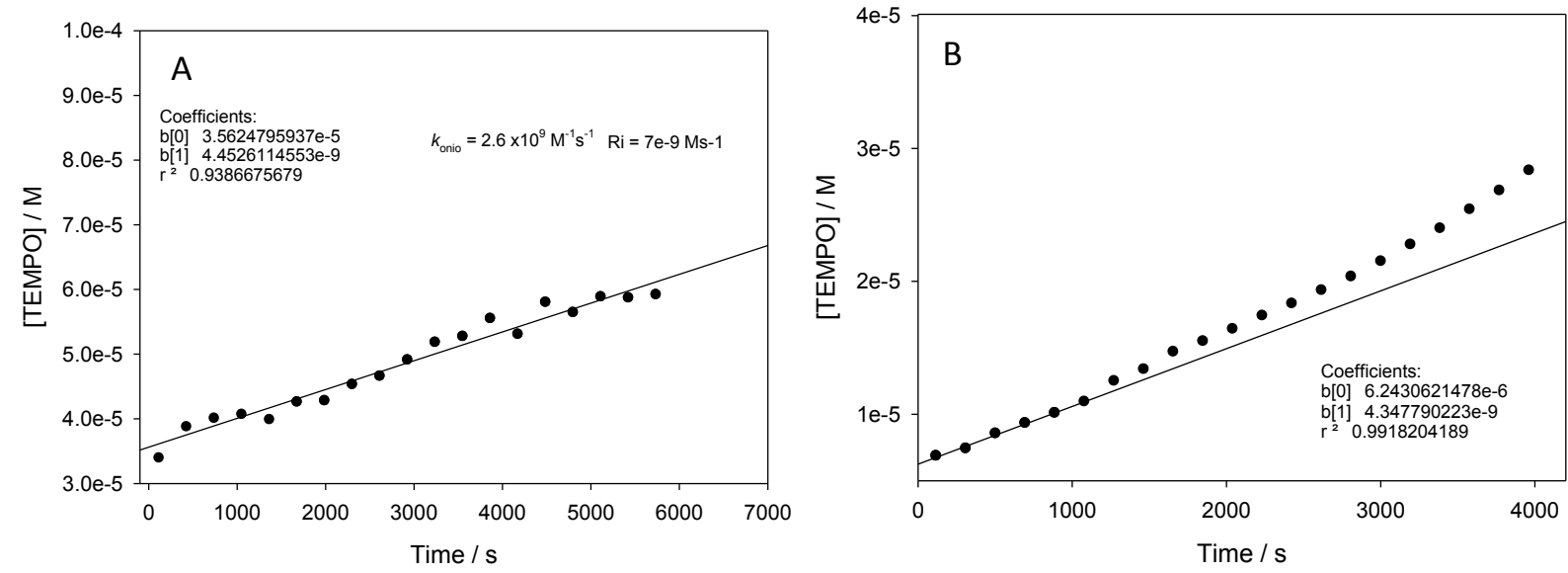

Figure S16. TEMPO concentration determined by EPR during the autoxidation of $40 \%(\mathrm{v} / \mathrm{v})$ cumene in chlorobenzene at $303 \mathrm{~K}$ initiated by AIBN $0.055 \mathrm{M}$ in the presence of $\mathrm{TEMPO}^{+} \mathrm{BF}_{4}^{-}(1.1 \mathrm{mM})$ in the presence of $35 \mathrm{mM}$ acetic acid (A) or without acid (B). In the absence of acid, the initial rate is noticeably slower and nonlinear - increasing with time, perhaps due to depletion of $\mathrm{O}_{2}$ over the longer period of time, improving the competition with alkyl radicals. 

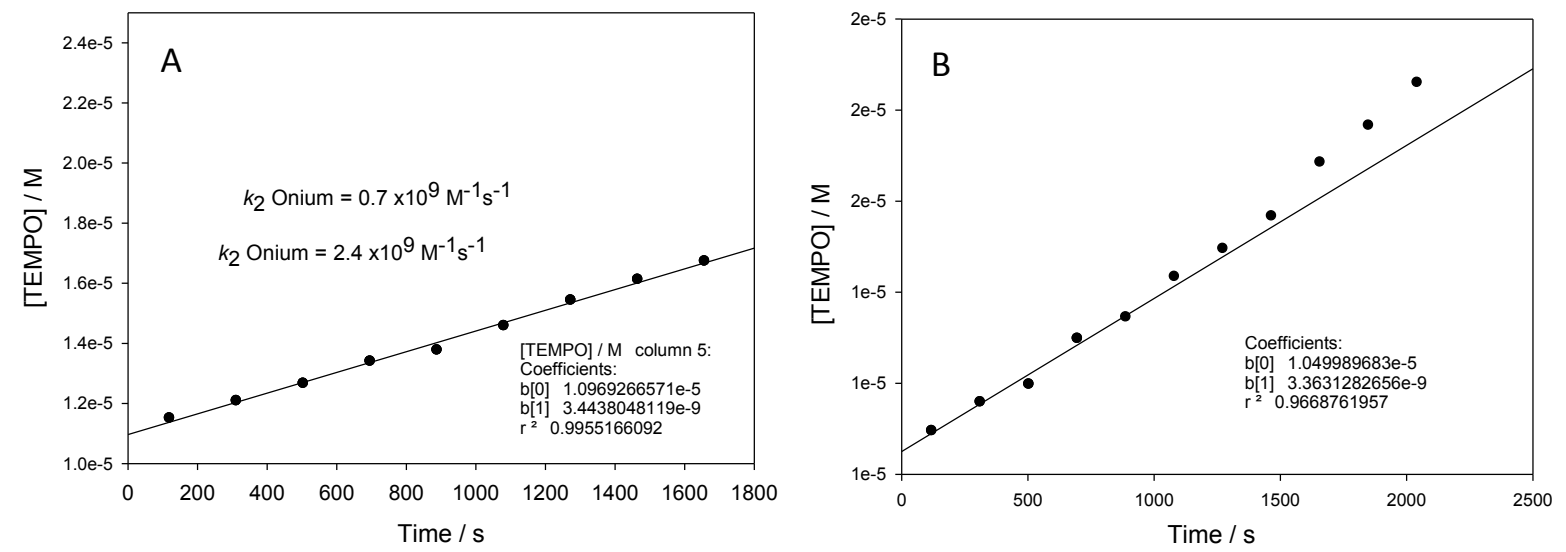

Figure S17. TEMPO concentration determined by EPR during the autoxidation (at $303 \mathrm{~K}$ initiated by AIBN $0.055 \mathrm{M})$ of $45 \%(\mathrm{v} / \mathrm{v})$ cumene in chlorobenzene in the presence of $\mathrm{TEMPO}^{+} \mathrm{BF}_{4}^{-}(0.67 \mathrm{mM})$ in the presence of $35 \mathrm{mM}$ acetic acid (A) or without acid (B).

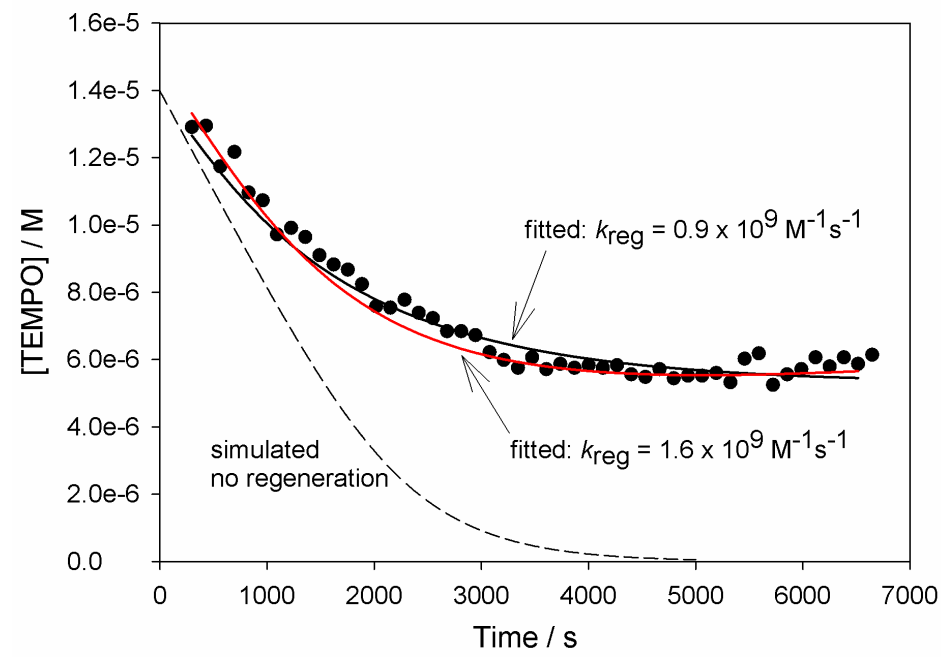

Figure S18. TEMPO concentration determined by EPR during the autoxidation of cumene $(45 \% \mathrm{v} / \mathrm{v})$ in chlorobenzene initiated by AIBN $0.05 \mathrm{M}$ at $303 \mathrm{~K}$, in the presence of TEMPO $1.4 \times 10^{-5} \mathrm{M}$ and acetic acid $52 \mathrm{mM}$. Simulations show the expected decay in the absence of TEMPO regeneration from TEMPO+, and the fitted traces allowing regeneration with the indicated $k_{\text {reg }}\left(=k_{\text {onium }}\right)$. 


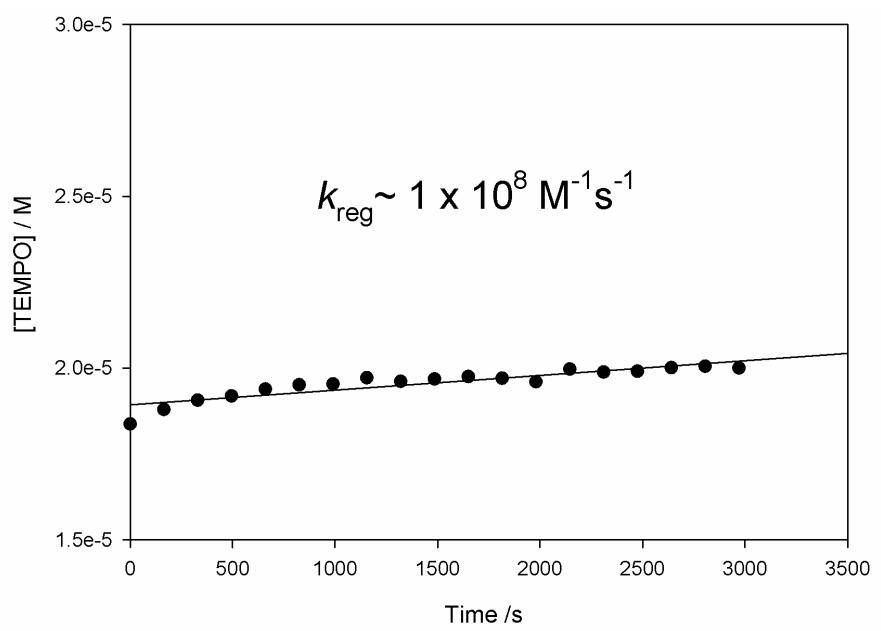

Figure S19. TEMPO concentration determined by EPR during the decomposition of AIBN $\left(0.05 \mathrm{M}, R_{\mathrm{i}}=\right.$ $\left.6.3 \times 10^{-9} \mathrm{Ms}^{-1}\right)$ in the presence of TEMPO ${ }^{+} \mathrm{BF}_{4}^{-}(3.5 \mathrm{mM})$ at $303 \mathrm{~K}$ in $\mathrm{MeCN}$. 


\section{High Temperature Autoxidations}

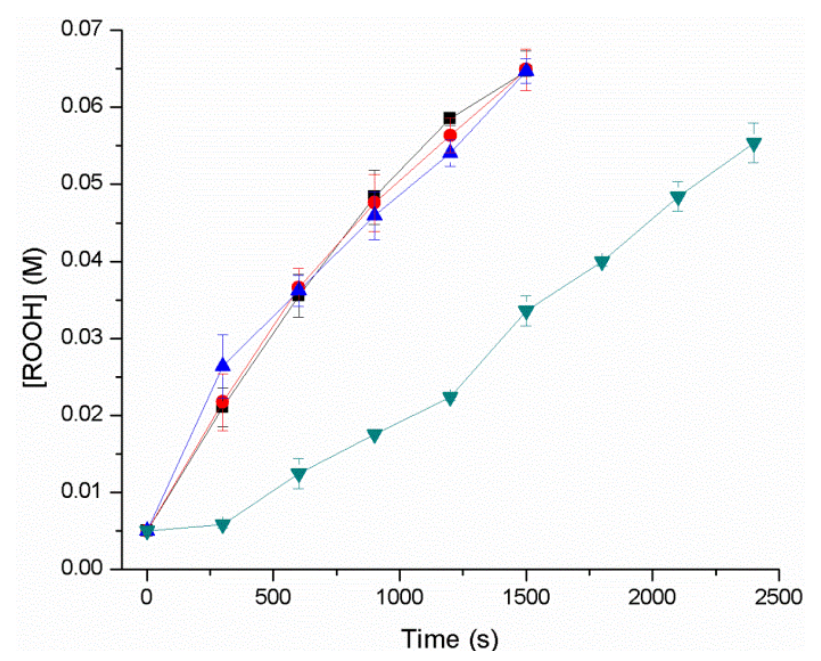

Figure S20. Hydroperoxide formation during the inhibited autoxidation of light paraffin oil at $160^{\circ} \mathrm{C}$, initiated by $5.0 \mathrm{mM}$ tetralin hydroperoxide, uninhibited without additives ( $\mathbf{\square})$, or with $40 \mathrm{mM} \mathrm{2,4,6-tri-}$ tert-butylpyridine (๑), $40 \mathrm{mM}$ palmitic acid $(\mathbf{\Delta})$ or inhibited with $40 \mu \mathrm{M}$ bis(nitroxide) $2(\boldsymbol{\nabla})$.

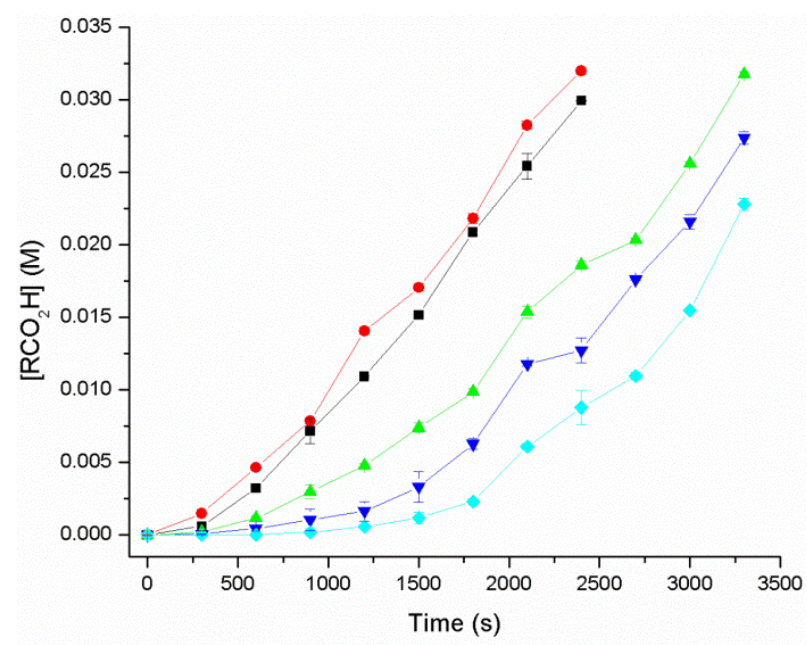

Figure S21. Carboxylic acid formation during the inhibited autoxidation of light paraffin oil at $160^{\circ} \mathrm{C}$, initiated by $5.0 \mathrm{mM}$ tetralin hydroperoxide, uninhibited without additives ( $\boldsymbol{\square})$, or with $40 \mathrm{mM} \mathrm{2,4,6-tri-}$ tert-butylpyridine (๑), or inhibited with $40 \mu \mathrm{M}$ bis(nitroxide) 2 with no additive (४), 2 with $4.0 \mathrm{mM}$ 2,4,6tri-tert-butylpyridine ( $\boldsymbol{\nabla})$, or 2 with $40 \mathrm{mM}$ 2,4,6-tri-tert-butylpyridine ( $\triangle$ ). 


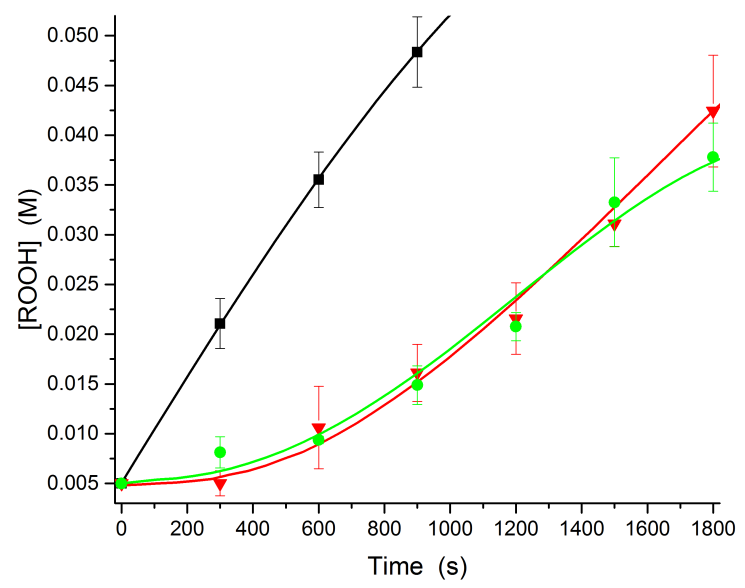

Figure 22. Hydroperoxide formation during the inhibited autoxidation of light paraffin oil at $160^{\circ} \mathrm{C}$, initiated by $5.0 \mathrm{mM}$ tetralin hydroperoxide, uninhibited without additives ( $\mathbf{\square})$, or inhibited with $40 \mu \mathrm{M}$ bis(nitroxide) $2(\boldsymbol{\nabla})$ or with $40 \mathrm{mM}$ of the bis(oxoammonium tetrafluoroborate salt) derived from $2(\bullet)$. 


\section{CBS-QB3 Computational Results and Structures}

$\underbrace{\stackrel{O^{\circ}}{1}}=\begin{array}{llll}\text { CBS-QB3 }(0 \mathrm{~K})= & -482.795331 & \text { CBS-QB3 Energy }= & -482.783208 \\ \text { CBS-QB3 Enthalpy }= & -482.782264 & \text { CBS-QB3 Free Energy }= & -482.832096\end{array}$

$\begin{array}{lrrr}02 & & & \\ \mathrm{C} & 1.33321700 & -0.06919700 & -0.02995600 \\ \mathrm{C} & -1.33321700 & -0.06919700 & -0.02995600 \\ \mathrm{C} & -1.24567600 & 1.40132600 & -0.48193500 \\ \mathrm{C} & 0.00000000 & 2.12648100 & 0.02592400 \\ \mathrm{C} & 1.24567600 & 1.40132600 & -0.48193500 \\ \mathrm{H} & -1.24350400 & 1.43269500 & -1.57766500 \\ \mathrm{H} & -2.15805100 & 1.91057200 & -0.15640400 \\ \mathrm{H} & 0.00000000 & 3.15965700 & -0.33442700 \\ \mathrm{H} & 0.00000000 & 2.18378900 & 1.11922500 \\ \mathrm{H} & 1.24350500 & 1.43269500 & -1.57766400 \\ \mathrm{H} & 2.15805100 & 1.91057200 & -0.15640300 \\ \mathrm{~N} & 0.00000000 & -0.74664400 & -0.20022700 \\ \mathrm{C} & 1.76850600 & -0.18385200 & 1.44528300 \\ \mathrm{H} & 1.70922100 & -1.22617600 & 1.76229500 \\ \mathrm{H} & 2.80139000 & 0.15710900 & 1.55691500 \\ \mathrm{H} & 1.14277600 & 0.41446000 & 2.10980900 \\ \mathrm{C} & 2.33773500 & -0.82266300 & -0.91474100 \\ \mathrm{H} & 3.32150000 & -0.35212100 & -0.83582500 \\ \mathrm{H} & 2.41463100 & -1.86414300 & -0.60607000 \\ \mathrm{H} & 2.02380200 & -0.79745100 & -1.96103100 \\ \mathrm{C} & -1.76850600 & -0.18385100 & 1.44528300 \\ \mathrm{H} & -2.80139000 & 0.15711000 & 1.55691600 \\ \mathrm{H} & -1.70922100 & -1.22617700 & 1.76229500 \\ \mathrm{H} & -1.14277500 & 0.41445900 & 2.10980900 \\ \mathrm{C} & -2.33773500 & -0.82266300 & -0.91474000 \\ \mathrm{H} & -2.41463100 & -1.86414300 & -0.60606900 \\ \mathrm{H} & -3.32150000 & -0.35212200 & -0.83582500 \\ \mathrm{H} & -2.02380200 & -0.79745200 & -1.96103100 \\ \mathrm{O} & 0.00000000 & -2.01663600 & -0.04332700\end{array}$




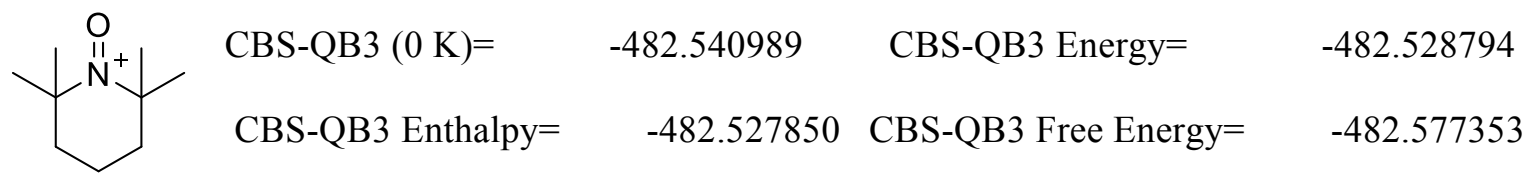

$\begin{array}{lrrr}11 & & & \\ \mathrm{C} & 1.36988900 & -0.07079700 & 0.00983700 \\ \mathrm{C} & -1.36988900 & -0.07079700 & 0.00983700 \\ \mathrm{C} & -1.25179400 & 1.33700600 & -0.61215200 \\ \mathrm{C} & 0.00000000 & 2.10829400 & -0.20032400 \\ \mathrm{C} & 1.25179500 & 1.33700600 & -0.61215200 \\ \mathrm{H} & -1.27723100 & 1.23801900 & -1.70204400 \\ \mathrm{H} & -2.15873100 & 1.87640700 & -0.32786300 \\ \mathrm{H} & 0.00000000 & 3.07875400 & -0.70144700 \\ \mathrm{H} & 0.00000100 & 2.32460500 & 0.87125200 \\ \mathrm{H} & 1.27723000 & 1.23801900 & -1.70204400 \\ \mathrm{H} & 2.15873200 & 1.87640700 & -0.32786400 \\ \mathrm{~N} & 0.00000000 & -0.78133600 & -0.11530400 \\ \mathrm{C} & 1.69114300 & -0.02779100 & 1.52441100 \\ \mathrm{H} & 1.62103000 & -1.01984900 & 1.97366800 \\ \mathrm{H} & 2.72621300 & 0.30819200 & 1.61187200 \\ \mathrm{H} & 1.06401300 & 0.66668500 & 2.07846500 \\ \mathrm{C} & 2.39928900 & -0.93253600 & -0.72344100 \\ \mathrm{H} & 3.34523200 & -0.38815500 & -0.71565100 \\ \mathrm{H} & 2.55671200 & -1.89550900 & -0.23934900 \\ \mathrm{H} & 2.11555500 & -1.10129000 & -1.76418900 \\ \mathrm{C} & -1.69114400 & -0.02779100 & 1.52441100 \\ \mathrm{H} & -2.72621400 & 0.30819000 & 1.61187100 \\ \mathrm{H} & -1.62102800 & -1.01984800 & 1.97366900 \\ \mathrm{H} & -1.06401500 & 0.66668700 & 2.07846500 \\ \mathrm{C} & -2.39928900 & -0.93253600 & -0.72344100 \\ \mathrm{H} & -2.55671200 & -1.89550800 & -0.23935000 \\ \mathrm{H} & -3.34523100 & -0.38815400 & -0.71565200 \\ \mathrm{H} & -2.11555400 & -1.10129000 & -1.76418900 \\ \mathrm{O} & 0.00000000 & -1.95292000 & -0.29680100\end{array}$




$\begin{array}{llll}\text { CBS-QB3 }(0 \mathrm{~K})= & -348.837138 & \mathrm{CBS}-\mathrm{QB} 3 \text { Energy }= & -348.827927 \\ \mathrm{CBS}-\mathrm{QB} 3 \text { Enthalpy }= & -348.826982 & \mathrm{CBS}-\mathrm{QB} 3 \text { Free Energy }= & -348.872592\end{array}$

$\begin{array}{lrrr}02 & & & \\ \mathrm{C} & 0.00005100 & 0.18619600 & 0.00000000 \\ \mathrm{C} & 0.00003000 & -0.56298500 & 1.21055100 \\ \mathrm{C} & -0.00006000 & -1.94815000 & 1.20468200 \\ \mathrm{C} & -0.00011700 & -2.65646200 & 0.00000000 \\ \mathrm{C} & -0.00006000 & -1.94815000 & -1.20468200 \\ \mathrm{C} & 0.00003000 & -0.56298500 & -1.21055100 \\ \mathrm{H} & 0.00008300 & -0.04321500 & 2.16025700 \\ \mathrm{H} & -0.00008600 & -2.48586500 & 2.14687000 \\ \mathrm{H} & -0.00021200 & -3.74024300 & 0.00000000 \\ \mathrm{H} & -0.00008600 & -2.48586500 & -2.14687000 \\ \mathrm{H} & 0.00008300 & -0.04321500 & -2.16025700 \\ \mathrm{C} & 0.00008100 & 1.61359000 & 0.00000000 \\ \mathrm{C} & 0.00003000 & 2.38028300 & -1.29293000 \\ \mathrm{H} & 0.00001600 & 3.45652100 & -1.11456200 \\ \mathrm{H} & 0.87859500 & 2.14892900 & -1.90933800 \\ \mathrm{H} & -0.87854800 & 2.14889400 & -1.90931300 \\ \mathrm{C} & 0.00003000 & 2.38028300 & 1.29293000 \\ \mathrm{H} & -0.87854800 & 2.14889400 & 1.90931300 \\ \mathrm{H} & 0.87859500 & 2.14892900 & 1.90933800 \\ \mathrm{H} & 0.00001600 & 3.45652100 & 1.11456200\end{array}$




$\begin{array}{llll}\mathrm{CBS}-\mathrm{QB} 3(0 \mathrm{~K})= & -348.591896 & \mathrm{CBS}-\mathrm{QB} 3 \text { Energy }= & -348.584395 \\ \mathrm{CBS}-\mathrm{QB} 3 \text { Enthalpy }= & -348.583450 & \mathrm{CBS}-\mathrm{QB} 3 \text { Free Energy }= & -348.624080\end{array}$

$\begin{array}{lrrr}11 & & & \\ \mathrm{C} & -0.00002500 & 0.17759900 & 0.00000000 \\ \mathrm{C} & -0.00001400 & -0.55691800 & 1.22452700 \\ \mathrm{C} & -0.00001400 & -1.93538000 & 1.21932300 \\ \mathrm{C} & -0.00001600 & -2.62579200 & 0.00000000 \\ \mathrm{C} & -0.00001400 & -1.93538000 & -1.21932300 \\ \mathrm{C} & -0.00001400 & -0.55691800 & -1.22452700 \\ \mathrm{H} & -0.00001100 & -0.03416800 & 2.17143400 \\ \mathrm{H} & -0.00001200 & -2.48409900 & 2.15251500 \\ \mathrm{H} & -0.00001400 & -3.71002300 & 0.00000000 \\ \mathrm{H} & -0.00001200 & -2.48409900 & -2.15251500 \\ \mathrm{H} & -0.00001100 & -0.03416800 & -2.17143400 \\ \mathrm{C} & -0.00003000 & 1.59279100 & 0.00000000 \\ \mathrm{C} & 0.00004000 & 2.36967100 & -1.27175200 \\ \mathrm{H} & 0.00009300 & 3.44185100 & -1.09400600 \\ \mathrm{H} & 0.87659000 & 2.11665400 & -1.87916200 \\ \mathrm{H} & -0.87651200 & 2.11674400 & -1.87919500 \\ \mathrm{C} & 0.00004000 & 2.36967100 & 1.27175200 \\ \mathrm{H} & -0.87651200 & 2.11674400 & 1.87919500 \\ \mathrm{H} & 0.87659000 & 2.11665400 & 1.87916200 \\ \mathrm{H} & 0.00009300 & 3.44185100 & 1.09400600\end{array}$




\section{References}

1) Ikeda, H.; Hoshi, Y.; Namai, H.; Tanaka, F.; Goodman, J. L.; Mizuno, K. Chem. Eur. J. 2007, 13, 9207-9215.

2) Hanthorn, J. J.; Synthesis, Thermodynamic and Kineic Studies of Novel Diarylamine Antioxidants \& Development of a Fluorescent Probe for Quantifying Hydroperoxides and Measuring H-Atom Transfer Kinetics with Peroxyl Radicals. Ph.D. dissertation. Queen's University, Kingston, ON. 2012.

3) Holan, M.; Jahn, U. Org. Lett. 2014, 16, 58-61.

4) Connolly, T. J.; Baldoví, M. V.; Mohtat, N.; Scaiano, J. C. Tetrahedron Lett. 1996, 37, 4919-4922.

5) Mendes, P. Trends Biochem. Sci. 1997, 22, 361-363.

6) Howard, J. A.; Ingold, K. U. Can. J. Chem. 1965, 43, 2729-2736.

7) Maillard, B.; Ingold, K. U.; Scaiano, J. C. J. Am. Chem. Soc. 1983, 105, 5095-5099.

8) Litwinienko, G.; Ingold, K. U. J. Org. Chem, 2005, 70, 8982-8990.

9) Chateauneuf, J.; Lusztyk, J.; Ingold, K. U. J. Org. Chem. 1988, 53, 1629-1632.

10) Amorati, R.; Pedulli, G. F.; Pratt, D. A.; Valgimigli, L. Chem. Commun. 2010, 46, 5139-5141.

11) McClelland, R. A.; Kanagasabapathy, V. M.; Banait, N. S.; Steenken, S. J. Am. Chem. Soc. 1991, 113, 1009-1014.

12) Ohkatsu , Y.; Fujiwara, T.; J. Japan Petroleum Inst. 2007, 50, 87-93.

13) Willenbacher, J.; Wuest, K. N. R.; Mueller, J. O.; Kaupp, M.; Wagenknecht, H.; and BarnerKowollik, C. ACS Macro Lett., 2014, 3, 574-579.

14) Cohen, S. G.; Groszos, S. J.; Sparrow, D. B. J. Am. Chem. Soc., 1950, 72, 3947-3951.

15) Shelton, J. R.; Liang, C. K. Synthesis, 1971, 204-205. 